\title{
EKSPLORASI ETNOMATEMATIKA PADA BATIK SEKAR JAGAD BLAMBANGAN SEBAGAI BAHAN AJAR SISWA
}

\author{
Nabilah Akmalia ${ }^{1}$, Sunardi ${ }^{2}$, Lioni Anka Monalisa ${ }^{2}$ \\ Program Studi Pendidikan Matematika, FKIP, Universitas Jember \\ Jalan Kalimantan 37 Kampus Tegalboto Jember 68121 \\ E-mail: nabilahakm22@gmail.com
}

\begin{abstract}
Ethnomathematics is an activity carried out by a group of cultures where they are unaware that there is a basic application or concept of mathematics in it. Learning mathematics needs an approach that is able to connect mathematics with everyday culture. One of the cultures possessed by Indonesia is batik art. Batik Sekar Jagad Blambangan is a typical batik in Banyuwangi. This research aimss to describe the results of ethnomathematics exploration of Batik Sekar Jagad Blambangan and make student teaching materials student worksheet especially for grade XI Senior High School with geometry transformation material. This study used qualitative research with an ethnographic approach. The subjects are 2 craftsmen at Godho Batik house production in Banyuwangi. Data were collected by using observation, interview, and documentation. The result of this study indicates the existence of ethnomathematics at Batik Sekar Jagad Blambangan.There are some geometry concepts or elements found, such as: points, lines, angles, 2D shapes, congruence and geometric transformations.
\end{abstract}

Keywords: Ethnomathematics, Batik Sekar Jagad Blambangan, Geometry

\section{PENDAHULUAN}

Pendidikan dipandang sebagai suatu kebutuhan hidup manusia. Pendidikan mempunyai peranan yang sangat penting bagi kehidupan masa sekarang. Dalam dunia pendidikan, matematika adalah salah satu bidang ilmu pengetahuan yang sangat dibutuhkan untuk mengembangkan bidang ilmu pengetahuan yang lainnya.

Matematika sebagai ilmu dasar yang memegang peranan sangat penting dalam pengembangan sains dan teknologi, karena matematika merupakan sarana berpikir untuk menumbuhkembangkan daya nalar, cara berpikir logis, sistematis, dan kritis [1]. Matematika sangat berpengaruh dalam kehidupan sehari-hari, tidak hanya berkaitan dengan hal-hal ilmiah saja namun hampir pada seluruh aspek kehidupan manusia tidak terlepas dari matematika. Setiap aspek kegiatan manusia dapat diuraikan menjadi suatu model pembelajaran khususnya pembelajaran matematika. Pembelajaran matematika sangat perlu

\footnotetext{
${ }^{1}$ Mahasiswa S1 Prodi Pendidikan Matematika FKIP Universitas Jember

${ }^{2}$ Dosen Prodi Pendidikan Matematika FKIP Universitas Jember
} 
adanya suatu pendekatan yang mampu menghubungkan antara matematika dengan budaya sehari-hari.

Peran budaya dalam pendidikan sangat penting khususnya matematika. Untuk dapat melihat kaitan matematika dengan budaya di kehidupan sehari-hari, ada suatu paham ilmu yang menjembatani keduanya yaitu etnomatematika. Etnomatematika didefinisikan sebagai cara-cara khusus yang dipakai oleh suatu kelompok budaya atau masyarakat tertentu dalam aktivitas matematika [2]. Etnomatematika adalah hasil aktivitas suatu suku yang didalamnya terdapat konsep-konsep matematika yang kadang tanpa disadari oleh masyarakat itu sendiri [3].

Indonesia merupakan negara yang memiliki semboyan Bhinneka Tunggal Ika, dimana Indonesia memiliki keberagaman budaya yang bervariasi. Salah satu kebudayaan dari Indonesia adalah batik. Batik adalah hasil kebudayaan asli bangsa Indonesia yang mempunyai nilai tinggi [4]. Banyuwangi merupakan salah satu daerah penghasil batik di Pulau Jawa tepatnya Provinsi Jawa Timur. Banyuwangi kaya akan jenis batik di antaranya adalah Gajah Oling, Kangkung Setingkes, Alas Kobong, Paras Gempal, Kopi Pecah, Gedegan, Ukel, Moto Pitik, Sembruk Cacing, Blarak Semplah, Gringsing, dan Sekar Jagad Blambangan.

Salah satu jenis batik yang memiliki ciri khas yaitu batik Sekar Jagad Blambangan. Batik Sekar Jagad Blambangan merupakan salah satu batik khas Banyuwangi yang tak kalah indah corak dan warnanya. Pada batik Sekar Jagad Blambangan ini terdapat konsep atau unsur geometri berupa sekumpulan motif-motif khas batik Banyuwangi yang mengandung makna keanekaragaman dan mewakili motif-motif batik Banyuwangi lainnya.

Berdasarkan uraian diatas, peneliti tertarik untuk melakukan eksplorasi terhadap etnomatematika pada Batik Sekar Jagad Blambangan dengan tujuan mengetahui konsep atau unsur geometri yang terkandung didalamnya dan menjadikannya sebagai bahan ajar siswa. Bahan ajar siswa yang digunakan berupa Lembar Kerja Siswa yang diharapkan dapat membantu siswa dalam proses pembelajaran. Lembar kerja siswa yang dimaksud dalam penelitian ini meliputi lembaran-lembaran yang berisi panduan secara terstrukstur dan soalsoal yang dapat membantu siswa untuk lebih memahami konsep atau unsur geometri. Dengan adanya Lembar Kerja Siswa berbasis etnomatematika pada batik Sekar Jagad Blambangan 
diharapkan dapat menambah minat dan memudahkan pemahaman siswa dalam memahami konsep atau unsur geomteri.

\section{METODE PENELITIAN}

Jenis penelitian yang digunakan dalam penelitian ini adalah penelitian kualitatif. Penelitian kualitatif adalah penelitian yang bermaksud untuk memahami teorema tentang apa yang dialami oleh subjek penelitian misalnya perilaku, persepsi, motivasi, tindakan, dan lainlain secara holistik dan dengan cara deskripsi dalam bentuk kata-kata dan bahasa, pada suatu konteks khusus yang alamiah dan dengan memanfaatkan berbagi metode alamiah [5]. Pada penelitian ini menggunakan penelitian kualitatif karena bermaksud untuk mendeskripsikan konsep atau unsur geometri yang terdapat pada Batik Sekar Jagad Blambangan.

Pendekatan yang digunakan dalam penelitian ini adalah pendekatan etnografi. Pendekatan etnografi bertujuan mendapatkan deskripsi dan analisis yang mendalam tentang kebudayaan berdasarkan penelitian lapangan yang intensif. Etnografi adalah suatu bentuk penelitian yang berfokus pada makna sosiologi melalui observasi lapangan tertutup dari fenomena sosiokultural [6]. Pendekatan etnografi pada penelitian ini digunakan untuk menggambarkan, menjelaskan, dan mengidentifikasi konsep atau unsur geometri yang terdapat pada Batik Sekar Jagad Blambangan.

Tempat yang digunakan dalam penelitian ini adalah Godho Batik yang bertempat di Perum Permata Giri Blok A7, Kecamatan Giri, Kabupaten Banyuwangi.

Subjek penelitian ini terdiri dari 2 orang, dimana S1 selaku pembatik di rumah produksi batik Godho Batik Banyuwangi dan S2 selaku pembuat pola/desain batik Sekar Jagad Blambangan di rumah batik Godho Batik.

Untuk memudahkan peneliti mencapai tujuan penelitian, tahap pertama yang harus dilakukan yaitu pendahuluan dimana pada tahap ini yang dilakukan adalah menentukan permasalahan yang akan dijadikan objek penelitian dan memilih tempat dan subjek penelitian. Tahap kedua adalah pengamatan, dimana pada tahap ini yang dilakukan adalah mengamati objek dan subjek penelitian. Tahap selanjutnya adalah pembuatan instrumen, dimana yang dilakukan pada tahap ini adalah membuat instrumen penelitian yang terdiri dari pedoman observasi dan wawancara. Tahap selanjutnya yaitu validasi instrumen, yang dilakukan pada tahap ini adalah memvalidasi instrument pedoman observasi dan wawancara 
kepada validator. Tahap selanjutnya yaitu pengumpulan data, pada penlitian ini pengumpulan data diperoleh dengan melakukan observasi, wawancara dan dokumentasi.

Observasi dilakukan dengan mengamati secara langsung aktivitas pembatik yang berkaitan dengan konsep atau unsur geometri di Godho Batik Banyuwangi. Dokumentasi dilakukan pada saat proses pembuatan desain batik. Wawancara dilakukan dengan memberikan pertanyaan sampai peneliti memperoleh data yang diperlukan. Tahap berikutnya adalah analisis data, langkah ini dilakukan digunakan untuk menjawab semua permasalahan dalam penelitian serta untuk mengidentifikasi konsep atau unsur geometri pada Batik Sekar Jagad Blambangan dan pada aktivitas membuat desain Batik Sekar Jagad Blambangan. Tahap selanjutnya yaitu membuat bahan ajar berupa Lembar Kerja Siswa dari hasil eksplorasi etnomatematika pada batik Sekar Jagad Blambangan. Tahap terakhir adalah kesimpulan. Peneliti membuat kesimpulan dari analisis data yang didapat untuk mengetahui bagaimana etnomatematika pada Batik Sekar Jagad Blambangan yang mengacu pada rumusan masalah.

\section{HASIL DAN PEMBAHASAN}

Berdasarkan hasil observasi pada batik Sekar Jagad Blambangan dan wawancara terhadap kedua subjek penelitian di rumah produksi batik Godho Batik diperoleh bahwa dalam proses pembuatan pola/desain dan hasil batik Sekar Jagad Blambangan terdapat unsur atau konsep geometri yang secara tidak sadar diterapkan oleh para pembatik. Unsur atau konsep geometri yang digunakan pada batik Sekar Jagad Blambangan meliputi: titik, garis, sudut, bangun datar, kesebangunan dan kekongruenan, serta transformasi geometri.

\section{Unsur Titik pada Batik Sekar Jagad Blambangan}

Batik mempunyai pengertian sebagai segala sesuatu yang berhubungan dengan membuat titik. Titik tidak dapat didefinisikan. Titik memiliki tempat namun berdimensi nol. Titik merupakan bagian dari isen, dimana unsur titik digunakan sebagai aksen tambahan untuk mengisi kekosongan pada motif serta menjadi alasan agar batik terlihat lebih indah. Berdasarkan observasi dan wawancara yang telah dilakukan pada penelitian ini, didapatkan hasil bahwa dalam pembuatan batik Sekar Jagad Blambangan terdapat pola titik. Titik digambar menggunakan canting isen. 
Titik dibuat menggunakan canting yang memiliki diameter paling kecil. Cara pembatik membuat titik yakni dengan cara memanaskan "malam" pada kompor yang telah disediakan, kemudian mengisi canting dengan "malam" dan menorehkannya diatas kain mori. Pembatik dalam menorehkan titik atau isen tersebut ada yang mengikuti pola yang ada dan ada yang secara suka-suka sesuai dengan kreatifitas pembatiknya dengan alasan keindahan. Tidak terdapat aturan pada jumlah titik yang akan dihasilkan. Namun titik yang dihasilkan memiliki ukuran yang berbeda, ada yang berukuran kecil dan ada juga yang berukuran lebih besar.

Menurut pembatik ukuran titik yang dihasilkan tergantung dengan lama tidaknya waktu dalam menorehkan malam pada kainnya. Untuk membuat titik dengan ukuran kecil pembatik menorehkan malam pada kain dengan waktu yang singkat. Sedangkan untuk membuat titik dengan ukuran yang lebih besar, pembatik menorehkan malam pada kain dengan waktu yang lebih lama. Selain itu ukuran titik yang dihasilkan juga tergantung pada malam yang ditorehkannya. Jika malam terlalu panas maka saat menorehkan pada kain akan mblobor dan menyebabkan ukuran titik akan menjadi lebih besar. Pola titik dapat dilihat pada Gambar 1 berikut.

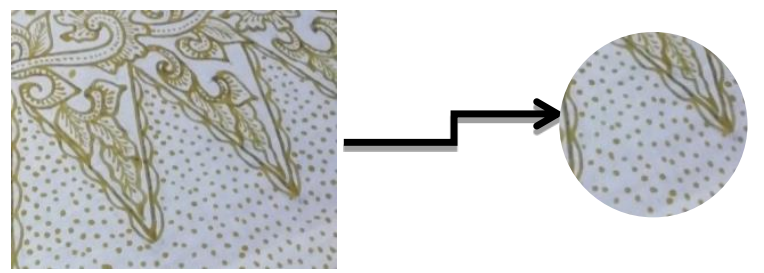

Gambar 1. Unsur Titik pada Batik Sekar Jagad Blambangan

\section{Unsur Garis pada Batik Sekar Jagad Blambangan}

Garis merupakan himpunan titik-titik yang tak hingga dan berdimensi satu. Apabila diberikan dua titik pada suatu garis, selalu ada titik yang terletak diantaranya pada garis tersebut. Berdasarkan observasi dan wawancara yang telah dilakukan dalam penelitian ini, didapatkan hasil bahwa dalam pembuatan batik terdapat unsur garis. Garis digunakan sebagai aksen tambahan untuk memenuhi kekosongan motif, untuk memperindah desain batik dan garis merupakan unsur dasar yang digunakan untuk membentuk suatu motif. Cara yang digunakan dalam membuat garis pada proses pencantingan yaitu dengan cara langsung manual dari canting. Pada tahap isen-isen, garis ditorehkan ada yang mengikuti pola yang ada dan juga ada yang tergantung dengan kreatifitas pembatiknya. Jumlah garis yang 
dihasilkan tidak ditentukan. Pembatik menorehkan malam dengan mengikuti pola yang telah digambar. Garis yang dihasilkan diantaranya yaitu garis lengkung dan garis lurus.

Pola garis pada motif gajah oling merupakan garis lengkung yang dibuat dengan alasan agar garis tampak seperti tulang daun. Pola garis pada motif gedhekan dan blarak sempleh merupakan garis lurus. Namun pada proses pencantingan garis yang dihasilkan terlihat tidak lurus lagi. Garis lurus yang termuat dalam persegi memiliki jumlah yang

Gambar 2(b), dan Gambar 2(c) berikut. berbeda tergantung dengan ukuran kotaknya dan berpola. Garis dibuat membujur dan melintang dan selang-seling tiap persegi. Menurut pembatik, garis dibuat membujur dan melintang agar terlihat seperti gedek (anyaman bambu) yang sesungguhnya. Pembatik juga menyebutkan jumlah garis tiap perseginya biasanya sama dan menyesuaikan ukuran persegi, namun biasanya kebanyakan pembatik membuat dengan jumlah yang ganjil. Jarak antar garis tidak diukur namun hanya diperkirakan saja. Pola garis dapat dilihat pada Gambar 2(a),

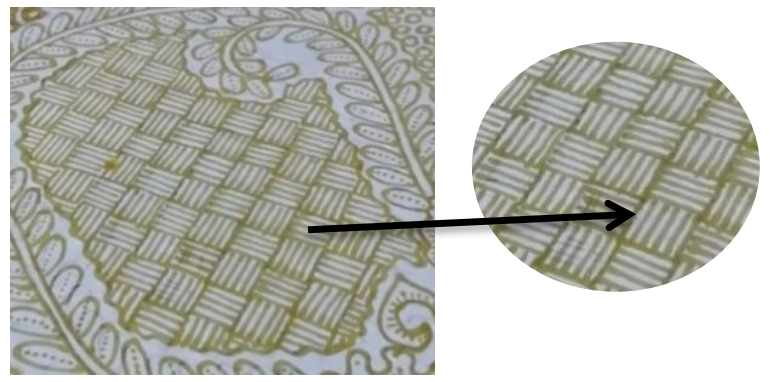

Gambar 2(a).

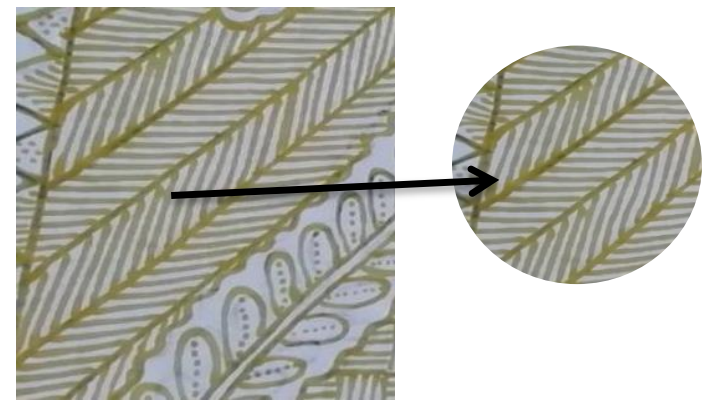

Gambar 2(b)

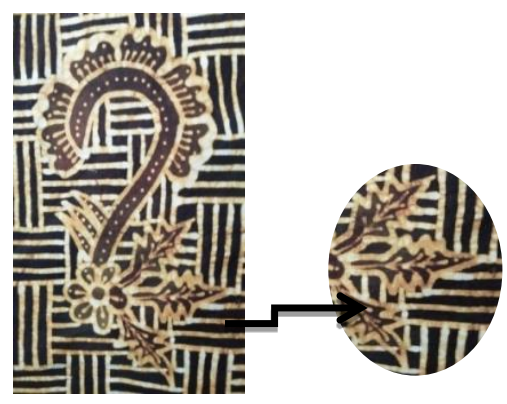

Gambar 2(c).

Gambar 3(a). Pola Garis pada Motif Gedhekan, 2(b). Pola Garis pada Motif Blarak Sempleh, 2(c). Pola Garis pada Motif Gedhekan

\section{Konsep Sudut pada Batik Sekar Jagad Blambangan}

Sudut didefinisikan sebagai pertemuan dua sinar garis yang memiliki titik pangkal 
yang sama. Sebuah sudut yang berukuran kurang dari $90^{\circ}$ disebut sudut lancip. Jika ukuran sudut tepat $90^{\circ}$, sudut tersebut adalah sudut siku-siku. Apabila ukuran sudut antara $90^{\circ}$ dan $180^{\circ}$, sudut tersebut adalah sudut tumpul. Sudut yang berukuran tepat $180^{\circ}$ adalah sudut berpelurus. Sudut refleks adalah salah satu sudut yang memiliki ukuran diantara $180^{\circ}$ dan $360^{\circ}[7]$.

Berdasarkan observasi dan wawancara yang telah dilakukan, etnomatematika muncul pada saat pembatik membuat pola sudut pada desain batik Sekar Jagad Blambangan. Pada batik Sekar Jagad Blambangan terdapat konsep sudut yaitu pertemuan dua garis pada satu titik pangkal yang sama. Terlihat pada batik dasar Sekar Jagad Blambangan (Gambar 3(a)), terdapat sudut lancip (sudut yang memiliki ukuran kurang dari 90) dan sudut siku-siku (sudut yang berukuran $90^{\circ}$ ). Sudut ini dibuat untuk mendapatkan motif tegas yang berbentuk segitiga pada dasar batik Sekar Jagad Blambangan dan sudut tersebut berasal dari garis miring yang ditarik dari pojok kotak ke pojok kotak yang saling berhadapan. Jenis sudut yang serupa terlihat pada pinggiran batik Sekar Jagad Blambangan, dimana sudut yang dihasilkan adalah sudut lancip (sudut yang memiliki ukuran kurang dari $90^{\circ}$ ). Menurut S2, sudut tersebut dibuat dengan alasan ingin membuat bangun segitiga dan sudut tersebut berasal dari dua garis yang arahnya naik dan turun jika diikuti dari kiri ke kanan dan berpola. Jenis sudut yang lain juga terdapat pada motif jenon (Gambar 3(b)), sudut yang dihasilkan adalah sudut lancip (sudut yang memiliki ukuran kurang dari 90 ) dan sudut tumpul (sudut yang berukuran antara $90^{\circ}$ dan $180^{\circ}$ ). Menurut S2, sudut tersebut dibuat dengan alasan akan membuat bangun persegi dan sudut tersebut berasal dari dua garis yang arahnya tegak dan mendatar.

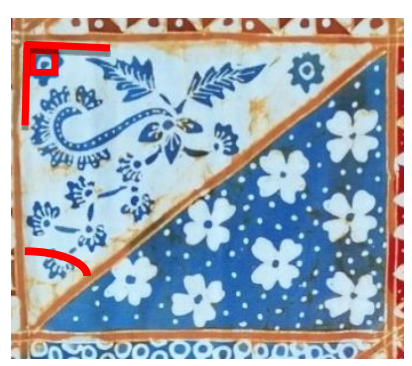

Gambar 3(a).

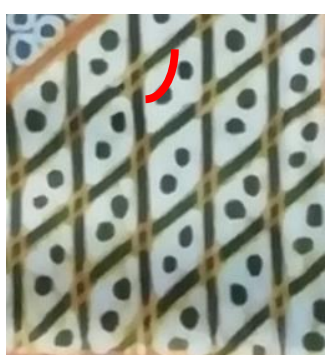

Gambar 3(b).

Gambar 3(a). Pola Sudut pada Motif Dasar Batik Sekar Jagad Blambangan, 3(b). Pola Sudut pada Motif Jenon 


\section{Konsep Bangun Datar pada Batik Sekar Jagad Blambangan}

Berdasarkan hasil penelitian pada batik Sekar Jagad Blambangan terdapat unsur bangun datar yakni segitiga, segiempat dan lingkaran. Segitiga yang dimaksud adalah segitiga siku-siku dan segitiga sama kaki. Segitiga siku-siku adalah segitiga dengan satu sudut siku-siku, sedangkan segitiga sama kaki adalah segitiga dengan paling sedikit dua sisinya sama panjang [7]. S2 menyebut segitiga pada motif dasar batik Sekar Jagad Blambangan dibuat dengan menarik garis vertikal dan garis horizontal sehingga membentuk beberapa kotak, kemudian menarik garis miring sehingga membentuk sebuah segitiga dalam setiap kotaknya. Pada motif pinggiran batik Sekar Jagad Blambangan terdapat bangun segitiga sama kaki dimana dua sisinya miliki panjang yang sama. Menurut S2, bangun tersebut dibuat dengan cara mengukur sisi bawahnya dan memperkirakan titik tengahnya kemudian menarik garis miring sehingga membentuk segitiga yang memiliki kaki yang beukuran sama panjang. Adapun segiempat yang dimaksud adalah persegi. Persegi adalah persegi panjang yang memiliki dua sisi yang berdekatan kongruen [7]. Pada motif gambir terdapat bangun persegi. Untuk membuat bangun persegi, S2 tidak mengukur panjang setiap sisinya hanya mengira-ngira agar ukuran setiap perseginya terlihat sama. Namun S2 menggunakan penggaris agar persegi yang dihasilkan terlihat lurus dan rapi.

Bangun datar lainnya yang terlihat dalam penelitian ini adalah lingkaran. Lingkaran adalah himpunan titik-titik yang memiliki jarak sama dari titik tertentu yang disebut titik pusat, dan jarak dari titik pusat ke titik pada lingkaran disebut jari-jari [7]. Dalam proses pembuatan lingkaran pada motif moto pitik tidak mengukur diameternya, hanya menggunakan perkiraan saja. Oleh karena itu lingkaran yang dihasilkan memiliki ukuran yang beragam, ada yang kecil dan ada yang lebih besar dibanding lingkaran yang lainnya. Pola bangun datar terdapat pada Gambar 4(a) dan Gambar 4(b) berikut.

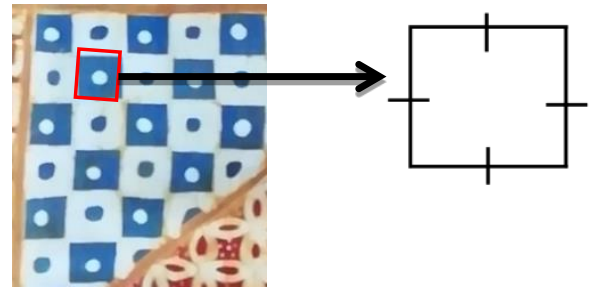

Gambar 4(a).

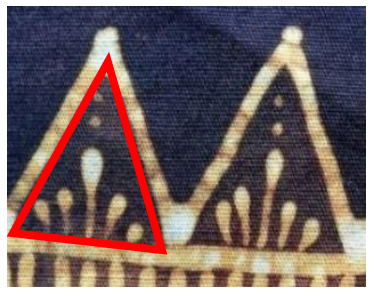

Gambar 4(b).

Gambar 4(a). Pola Bangun Datar pada Motif Gambir Gambar 4(b). Pola Bangun Datar pada Pinggiran Batik Sekar Jagad Blambangan 


\section{Konsep Kesebangunan dan Kekongruenan pada Batik Sekar Jagad Blambangan}

Apabila dua bangun geometri memiliki bentuk yang sama maka dua bangun tersebut dikatakan sebangun. Apabila dua bangun memiliki bentuk yang sama dan semua sisi dan sudut yang bersesuaian memiliki ukuran yang sama, maka kedua bangun tersebut dikatakan kongruen [7]. Berdasarkan hasil penelitian terdapat konsep kesebangunan dan kekongruenan pada batik Sekar Jagad Blambangan. Konsep kesebangunan terlihat pada motif moto pitik, dimana lingkaran yang dihasilkan memiliki bentuk yang sama namun memiliki ukuran yang berbeda setiap satuannya. Menurut pembuat desain, dalam pembuatan lingkaran pada motif moto pitik tersebut tidak menggunakan ukuran atau cara khusus karena motif terlalu kecil sehingga cukup menggunakan perkiraan saja. Oleh karena itu, lingkaran yang dihasilkan memiliki ukuran yang beragam. Konsep kesebangunan juga terlihat pada ornamen yang terletak diatas motif gajah oling. Ornamen tersebut memiliki bentuk yang sama namun memiliki ukuran yang berbeda setiap satuannya. S2 mengaku tidak ada cara khusus dalam membuat ornamen pada bagian atas motif gajah oling tersebut, cukup menggunakan perkiraan saja untuk menghasilkan bentuk yang sama. Sedangkan pada ukurannya ornamen tersebut memiliki ukuran yang berbeda karena dalam pembuatannya hanya menggunakan cara manual langsung digambar begitu saja.

Konsep kekongruenan terlihat pada motif gajah oling, dimana motif gajah oling tersebut memiliki bentuk dan ukuran yang sama dengan motif gajah oling disebelahnya. Cara pembuatannya yaitu dengan membuat terlebih dahulu satu motif gajah oling dan kemudian dijiplak agar memiliki bentuk dan ukuran yang sama persis, hanya perlu menjiplak pada bagian yang lain sesuai dengan keinginannya. Pola kesebangunan dan kekongruenan dapat dilihat pada Gambar 5(a) dan Gambar 5(b) berikut.
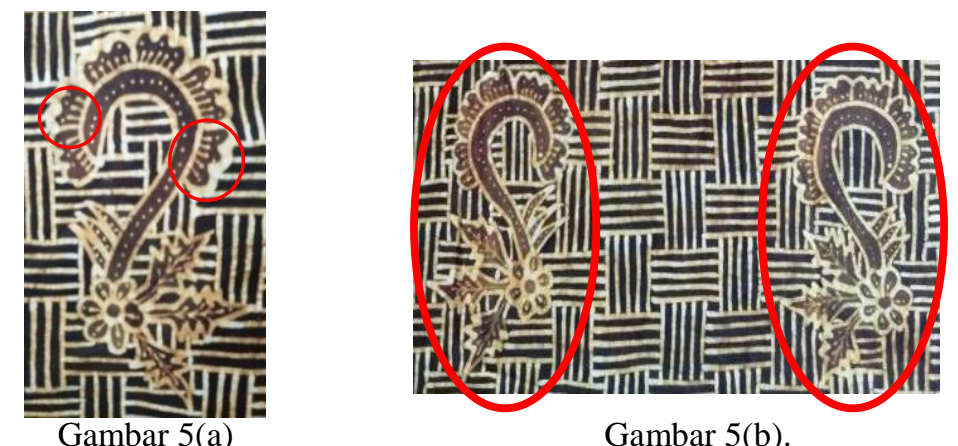

Gambar 5(a). Pola Kesebangunan pada Motif Gajah Oling, 5(b). Pola Kekongruenan pada Motif Gajah Oling 


\section{Konsep Transformasi Geometri pada Batik Sekar Jagad Blambangan}

Konsep transformasi geometri yang terdapat pada batik Sekar Jagad Blambangan antara lain translasi (pergeseran), refleksi (pencerminan), rotasi (perputaran) dan dilatasi.

1. Translasi

Translasi (pergeseran) merupakan salah satu jenis transformasi yang bertujuan untuk memindahkan semua titik suatu bangun dengan jarak dan arah yang sama [8]. Berdasarkan hasil penelitian terdapat konsep translasi pada batik Sekar Jagad Blambangan. Konsep translasi terlihat pada motif gajah oling yang memiliki bentuk. S2 memiliki cara khusus untuk membuat motif gajah oling tersebut agar memiliki bentuk dan ukuran yang sama. Cara pembuatannya yaitu dengan cara menjiplak. S2 membuat terlebih dahulu motif gajah oling tersebut pada kertas kecil dan kemudian dijiplak berulang secara horizontal yang mengakibatkan translasi, sehingga motif yang dihasilkan memiliki bentuk dan ukuran yang sama dengan jarak pergeseran yang hanya menggunakan perkiraan saja agar terlihat sama. Pola translasi dapat dilihat pada Gambar 6 berikut.

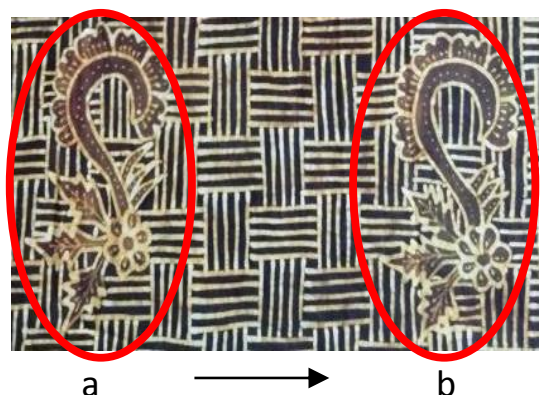

Gambar 6. Pola Translasi pada Motif Gajah Oling

\section{Refleksi}

Refleksi (pencerminan) merupakan satu jenis transformasi yang memindahkan setiap titik pada suatu bidang dengan menggunakan sifat bayangan cermin dari titik-titik yang dipindahkan [8]. Sifat dari bayangan benda yang dibentuk oleh pencerminan antara lain bentuk dan ukuran dari bayangan suatu bangun yang dicerminkan sama dengan bangun aslinya; jarak bayangan ke cermin sama dengan jarak cermin ke benda aslinya; bayangan suatu bangun pada cermin saling berhadapan dengan bangun aslinya [8]. Berdasarkan hasil penelitian terdapat konsep refleksi pada batik Sekar Jagad Blambangan. Konsep refleksi dapat dilihat pada motif gajah oling Pada motif tersebut terlihat bahwa sisi kanan dan sisi kiri memiliki bentuk dan ukuran yang sama seperti dicerminkan. S2 mengatakan bahwa terdapat 
cara khusus untuk membuat pola tersebut yakni dengan cara menjipak. Untuk menjiplak di sisi sebelahnya, S2 membuat jiplakan tersebut agar arahnya menjadi berlawanan. Sehingga gambar yang dihasilkan memiliki bentuk dan ukuran yang sama dan terlihat seperti dicerminkan. Refleksi yang digunakan adalah refleksi terhadap sumbu Y. Pola refleksi dapat dilihat pada Gambar 7 berikut.

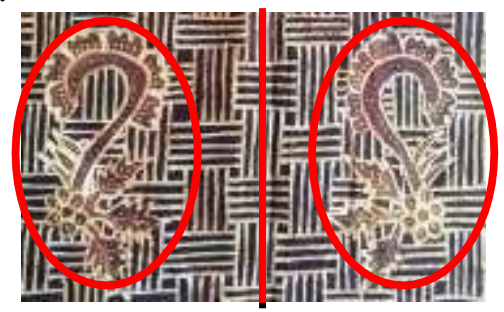

Gambar 7. Pola Refleksi pada Motif Gajah Oling

\section{Rotasi}

Rotasi (perputaran) merupakan salah satu bentuk transformasi yang memutar setiap titik pada gambar sampai sudut dan arah tertentu terhadap titik yang tetap. Titik tetap tersebut disebut pusat rotasi. Bayangan dan bangun asli dalam suatu rotasi selalu kongruen [8]. Hasil penelitian menunjukkan bahwa etnomatematika muncul pada desain batik Sekar Jagad Blambangan dan proses pembuatannya. Etnomatematika tersebut ditandai dengan munculnya konsep rotasi pada motif kawung, dimana pada motif tersebut terlihat perpuataran pada biji kawung yang tampak diputar sebesar 90. S2 tidak menggunakan cara khusus. Dalam pembuatannya, kawung-kawung tersebut secara berputar berurutan sampai membentuk satu motif kawung. Biasanya S2 membuat dari sisi atas terlebih dahulu, kemudian sisi kanan, sisi bawah dan kemudian yang terakhir sisi kiri sampai membentuk motif kawung yang berjumlah banyak. Pola rotasi dapat dilihat pada Gambar 8 berikut.

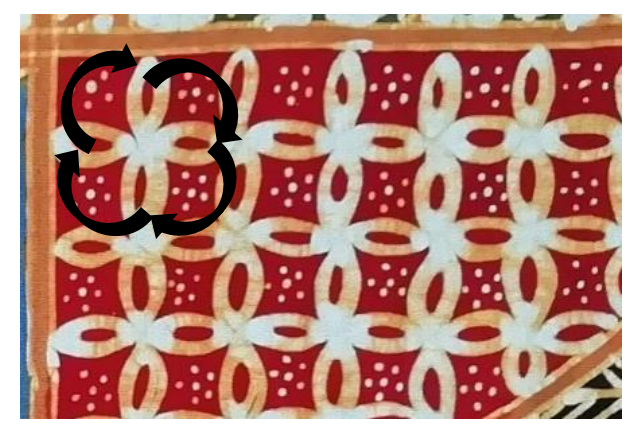

Gambar 8. Pola Rotasi pada Motif Kawung 


\section{Dilatasi}

Dilatasi terhadap titik pusat merupakan perkalian dari koordinat tiap-tiap titik pada suatu bangun datar dengan faktor skala sebesar $k$. Faktor skala menentukan apakah suatu dilatasi merupakan pembesaran ataupengecilan [8]. Hasil penelitian menunjukkan bahwa etnomatematika muncul pada desain batik Sekar Jagad Blambangan dan proses pembuatannya. Konsep dilatasi dapat dilihat pada segitiga yang digunakan sebagai pinggiran batik Sekar Jagad Blambangan. S2 selaku pembuat pola/desain batik mengatakan untuk membuat perbedaan ukuran tersebut dengan alasan keindahan dan hanya dengan menggunakan perkiraan saja. S2 membuat dengan cara yang pertama membuat ornamen yang berukuran besar kemudian membuat lagi yang berukuran lebih kecil dari sebelumnya tanpa adanya perbandingan ukuran khusus harus berapa kali dari ukuran awal. Pola dilatasi dapat dilihat pada Gambar 9 berikut.

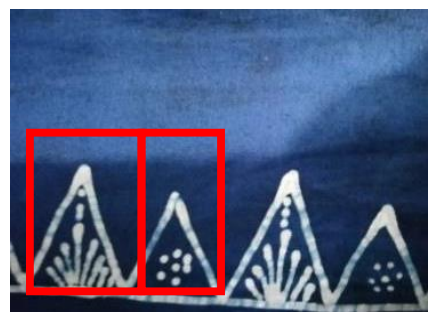

Gambar 9. Pola Dilatasi pada Pinggiran Batik Sekar Jagad Blambangan

\section{Bahan Ajar Siswa}

Bahan ajar merupakan segala bahan yang disusun secara sistematis, yang menampilkan sosok utuh dari kompetensi yang akan dikuasai peserta didik dan digunakan dalam proses pembelajaran dengan tujuan perencanaan dan penelaahan implementasi pembelajaran [9]. Hasil dalam penelitian ini dibuat produk bahan ajar siswa berupa Lembar Kerja Siswa(LKS).

LKS berupa bahan cetak yang dapat digunakan untuk membantu siswa belajar secara terprogram dan terarah [10]. Menurut Ernawati dkk., Lembar Kerja Siswa (LKS) dapat memudahkan peserta didik dalam memahami materi yang diberikan oleh pendidik, dimana LKS kaya akan tugas untuk berlatih dan melatih kemandirian belajar siswa [11].

Berdasarkan hasil penelitian, pokok bahasan yang akan diangkat yaitu indikatorindikator yang dapat teramati dengan baik dan bisa diterapkan dalam perhitungan serta konsep matematika. Pada LKS ini pokok bahasan materi yang akan diangkat adalah 
transformasi geometri serta dicantumkan pula konsep atau unsur geometri lainnya yang teramati dengan baik dalam penelitian.

LKS yang dihasilkan memuat kompetensi dasar, kompetensi inti, indikator pencapaian pembelajaran, deskripsi terkait batik Sekar Jagad Blambangan, ringkasan materi terkait unsur atau konsep geometri, panduan secara terstruktur, soal open ended tentang unsur titik dan garis, konsep sudut, konsep bangun datar, konsep kesebangunan dan kekongruenan, lembar kerja pada materi transformasi geometri serta latihan soal dengan materi transformasi geometri. Lembar kerja pada materi transformasi geometri serta latihan soal dengan materi transformasi geometri untuk kelas XI SMA kurikulum 2013. https://drive.google.com/open?id=1bAOP_BTP7XyT3pXe6CBmCKxtmu1m8B3R

\section{KESIMPULAN}

Berdasarkan hasil observasi pada batik Sekar Jagad Blambangan dan wawancara terhadap kedua subjek penelitian pada batik Sekar Jagad Blambangan, etnomatematika muncul pada saat pembatik membuat pola/desain dan pada hasil batik Sekar Jagad Blambangan terdapat unsur titik dan garis serta konsep sudut, bangun datar (segitiga, segiempat dan lingkaran), kesebangunan dan kekongruenan, transformasi geometri (translasi, refleksi, rotasi dan dilatasi). Pada saat proses pembuatan unsur atau konsep geometri pembatik menggunakan cara pengukuran atau cara perkiraan. Lembar Kerja Siswa yang dihasilkan dalam penelitian ini berupa ringkasan materi terkait unsur atau konsep geometri, panduan secara terstruktur, soal open ended tentang unsur titik dan ruas garis serta konsep sudut, bangun datar, kesebangunan dan kekongruenan, lembar kerja materi transformasi geometri serta latihan soal dengan materi transformasi geometri untuk kelas XI SMA kurikulum 2013.

\section{DAFTAR PUSTAKA}

[1] Hobri. (2010). Metodologi Penelitian Pengembangan Aplikasi pada Penelitian Pendidikan Matematika. Jember: Pena Salsabila.

[2] Rahmawati, I. (2012). Eksplorasi Etnomatematika Masyarakat Sidoarjo. Jurnal MATHEdunesa, 1(1). 
[3] Zayyadi, M. (2017). Eksplorasi Etnomatematika Pada Batik Madura. Sig $\Sigma a, 2(2), 35-$ 40.

[4] Istiqfarna, R. (2018). Karakteristik Batik Tulis Sumbersari Maesan Bondowoso. Skripsi. Surakarta: Fakultas Seni Rupa dan Desain Institut Seni Indonesia Surakarta.

[5] Moleong, L. J. (2016). Metodologi Penelitian Kualitatif. Bandung: PT Remaja Rosdakarya Offset.

[6] Emzir. (2010). Metodologi Penelitian Pendidikan Kuantitatif dan Kualitatif. Jakarta: Rajawali Pers.

[7] Alexander, D.C., \& Koberlein, G. M. (2011). Elementary Geometry for College Students. Canada: Brooks/Cole. Cengage Learning.

[8] Kemendikbud. (2018). Matematika Kelas IX SMP. Jakarta: Pusat Kurikulum dan Pembukuan, Balitbang Kemendikbud.

[9] Prastowo, A. (2011). Panduan Kreatif Membuat Bahan Ajar Inovatif. Yogyakarta: Diva Press.

[10] Kholilah, Y. N., Mahardika, I. K., \& Sutarto. (2016). Kelayakan Lembar Kerja Siswa (LKS) Berbasis Proyek untuk Pembelajaran IPA di SMP. Jurnal Pembelajaran dan Pendidikan Sains, 1(1), 1-8.

[11] Haryonik, Y., \& Bhakti, Y.B. (2018). Pengembangan Bahan Ajar Lembar Kerja Siswa dengan Pendekatan Matematika Realistik. MaPan: Jurnal Matematika Dan Pembelajaran, 6(1), 40-55. 